\title{
Contemporary Trends in the Catholic Teaching on the Eucharist*
}

\section{Catholic Church's Statements about the Eucharist}

The Church's task is to guard the mystery of the Eucharist and to pass it on from generation to generation. The Church believes that it receives the support of the Holy Spirit in carrying out its mission and the awareness of this fact authorized its teaching office to preach its doctrine over the centuries.

In fulfilling this vocation, the Church never intended to formulate, once and for all (in specific wordings), the whole truth. Often it was about statements related to a given historical epoch, statements directed against certain heresies in order to salvage the Christian truth.

The teaching of the Council of Trent on the Eucharist is extremely polemical, set in a climate created by the statements of reformers. Hence, it would be impossible to attempt to build a systematic treatise on the Eucharist based on the resolutions of the Council of Trent which focused all its attention on those parts of teaching on the Lord's Supper which met with the strong objections of the reformers in an impressive way defending the teaching of the Church's Tradition. A theologian therefore must be confronted with the following question: What Christian values of the Gospel were then attempted to be saved? The answer to this question takes the form of an imperative: We have an obligation to teach these essential values using language and methods of expression appropriate to our times.

So what is actually crucial in the dogma of the Council of Trent?

In the formation of this dogma, we can distinguish three levels: a. Level of faith. Although the senses only experience bread after consecration there is no bread but the Body of Christ. In this case simply a fact is stated

* STV 11(1973)2. The article is a paper presented during the nationwide session/conference of Polish dogmatists, which took place in Ołtarzew on October 24, 1972. 
without closer investigation on the particular way in which this transformation proceeds;

b. The ontological level: The bread is transformed into the Body of Jesus Christ. The term "transformation" is already the result of a certain reflection on the process "stated" by faith;

c. Philosophical and natural level: This transformation is called aptissime transubstantiation. The speculative analysis of the Eucharistic event has already taken place on this level.

The first and second level of the Eucharistic event form an unchangeable and lasting element of dogmatic statement. The third one, however, requires clarification. Its content was expressed through the use of Aristotelian-scholastic conceptual tools, which the Council of Trent did not intend to canonize. Here, therefore, there has been an autonomous space for theological research created.

Let us remain for a moment at the resolutions of the Council of Trent because there one can find the origins and motivations of contemporary attempts to present the study of the Eucharist. With full recognition of the prominent achievements of the Council Fathers of the Trent, addressing them with the objection that they created a break between the real Presence and the Sacrifice and Communion should not be considered as an attempt to undermine their exceptional role.

To justify this attitude, it should be added immediately that the Fathers of the Council of Trent were not able to act in any other way, for since the period of the disputes with Berengarius, which kept the full attention of theologians, the basic problem was the real presence of the Body and Blood of Christ.

In its legacy, the Council of Trent passed to the subsequent era a great and appreciative task: the creation of the necessary synthesis and the introduction of systematics between the three parts of the teaching about the Eucharist. Unfortunately post-Trent theology has not undertaken this mission.

All the pietism of the new era has focused on the cult of Christ present in the Eucharist in a bodily manner, which takes place not only during the Mass. The incidental, trichotomic scheme of the Council of Trent was taken over by the post-Vatican II theology, so that it was introduced as binding for catechisms and theological textbooks, and the first part of the trichotomy of the Treaty on the Eucharist was largely expanded.

It is surprising that this modernly criticized trichotomy scheme has been copied in the latest textbook of dogmatic theology, published by J. Auer and J. Ratzinger ${ }^{1}$. The following issues are discussed there: the problem of real 
presence, of the Eucharist as a sacrificial Feast and of the Holy Communion. In the meantime, it is true that the first and fundamental theorem of the teaching about the Eucharist is: this is My body, which is given to you, and not: under these species I am present. We offer Christ as our sacrifice and we receive Him.

This seems to imply that the whole meaning of making Christ present in the Eucharist is reduced to the act of receiving the Host, and that is why He becomes present ${ }^{2}$.

Among the reflections on the Eucharist, first place is occupied by the Lord's Supper which is tantamount to sacrifice and food.

\section{Ideological Tensions}

In the teaching about the Eucharist, two trends, seemingly paradoxical, run in parallel: while the extraordinary teaching office, opposing the pressure of heretical opinions, highlighted mostly the real presence, the ordinary Magisterium office from the beginning of Christianity never lost interest in the Eucharist in its entirety (e.g. in the liturgy). The conviction that the Eucharist is the Sacrifice of the Holy Mass including the presence of the whole saving work of Christ being his real presence and the presence oriented towards communion was developing in an organic way.

While elaborating the study on the Eucharist, we must not forget about these two tendencies of the Church's teaching. A synoptic view of these two trends leads us to the following view of the holistic vision of the Eucharist: the Eucharist is the sacramental presence of the whole of Christ's reality or the integral event of Jesus in order that the faithful could receive this saving gift through consuming the Eucharist ${ }^{3}$.

\section{Methodological Starting Point}

The above reflections lead us to the problem of the methods used by theological thought when considering the mystery of the Eucharist. At the beginning, chronologically and materially, there is a historical-redemptive method proper to the Scripture and the Fathers of the Church, and today, newly rediscovered

2 Cf. K. Rahner, Die Gegenwart Christi im Sakrament des Herrenmahles, in: Schriften zur Theologie, vol. 4, Zürich 2 1961, 384.

3 Cf. J. Betz, Lexikon für Theologie und Kirche 2 III, col. 1154. 
and revaluated, probably leads to the original understanding of the mystery of the Eucharist. Along with the decline of the biblical understanding of the history of salvation, and especially in connection with the decline of conviction of the existence of strict connection between the Sacrifice of the Holy Mass and Passover, the place of the historical-redemptive aspect is occupied by the allegorical-symbolic method. It could be expected that unrestrained over-interpretations and exaggerations of this method will have to trigger an appropriate response. This objection was justifiably expressed in the philosophical and metaphysical method which probably stood firmly in guard of the Eucharistic reality. The concept of transubstantiation, sanctioned by the Fourth Lateran Council, was elaborated here.

On the Evangelical side, where from the very beginning of the Reformation the Mass was strongly opposed as a sacrifice, and the Eucharist was conceived as a feast exercised by the commune, the phenomenological-idealistic method was used with the predilection. Again, the mystery theory of O. Casel and the liturgical movement paved the way for the renaissance of historical-redemptive biblical thinking. Paying attention to the historical aspect of the Eucharist is an extremely important and prolific discovery in the context of reflection on the Eucharist. Only this method makes it possible to capture the essential components of this sacrament.

Any other methods contribute to the development of the study of the Eucharist, if they concentrate on preserving the historical-redemptive approach. This short methodical outline mentioned here only pro memoria ${ }^{4}$ is a transition to today's newest approaches to the study of the Eucharist, to the attempts to capture its problems from the position of existential phenomenology. Behind all our previous observations was the implicit intention of pointing out the important fact that it is only in a relative sense that it is possible to speak of a "new" approach to the Eucharist or even a "new theology" at all.

Theology practiced in a responsible manner never begins its activity from point zero. It either takes over the theological aphorias, i.e. problems unresolved by its previous representatives, or formulates its own questions about the unchanging content of the revealed truths, questions from the position of a believer who is living in the twentieth century. Nevertheless it should be noted that this theology clearly distinguishes between the content of Revelation and the ways it is formulated ${ }^{5}$.

4 Cf. J. Auer, J. Ratzinger, Kleine katholische Dogmatik, vol. 6, $133 \mathrm{f}$.

5 The core of the matter is reflected in several concepts that are difficult to translate into Polish: continuité dans la discontinuité, with roughly speaking, the continuité would refer 


\section{Today's Hermeneutics of Statements about the Eucharist}

Due to the fact that today we elaborate the hermeneutics of the statements of the Teacher Office of the Church, interpreting them in the context of the historical, social and cultural conditions and other factors, thus trying to extract the essence of these judgments for its new, contemporary to us, valorizations, we also have a duty to investigate the background and conditions of today's trends in Eucharistic thought. It will thus not be so much about the presentation of different aspects of these tendencies but a more general issue: an attempt to recognize genetic assumptions of contemporary profiling of the teaching of Eucharist.

One of the characteristic features of our culture is a different attitude of man in relation to reality. A rational, conceptualist position is contrasted with another point of view on reality: a phenomenological attitude. Existential phenomenology holds the assumption that human consciousness is oriented, per se, to the reality that appears phenomenally to us; it is the attitude of being open to reality, which in turn reveals itself to our consciousness. Man experiences himself as a world-oriented being - the world of things and people.

In communing with the world, man does not appear as a passive receptor of external reality. On the contrary, he feels actively rooted in this reality. This reality is complex and elaborated to such an extent that it can be said that every human being creates his own world. The shape of the world depends in large part on the attitude of my consciousness. In order to exemplify this issue, one can say: I can pass by trees indifferently, yet an ordinary tree conceals in itself many meanings. Their quality depends on me. In a different way, a carpenter will look at a tree in a different way than a gardener or a learned dendrologist. All this applies even more to the man and his fellowman. Characterologically, it means that man is distinct from his phenomenal being.

Therefore, he is not a man of self-confidence, but a man who learns his own imperfection and who is listening with respect to the world and to other people with his entire personality. Incidentally, we can note here that this perspective explains to us the origins of today's man's opening to dialogue, meeting, ecumenical movement, and even to dialogue with Marxism, to change of the profile of education, sincere exchange of opinions between parents and the child - all this together undoubtedly affects the irenic formation of today's man.

to the content, while discontinuité would emphasize the diversity of the external expression of the revealed truth, while emphasizing the essential continuity which occurs between the substantive content and the new wording. 
It is, therefore, a different context from the one which was typical, for the most part, for older conceptualism and deductive thinking, when the interlocutors participating in the dispute were not so much in dialogue, but with more or less bravery, they tried to fight each other. In the textbooks of dogmatics of this type, after the thesis with its theological qualification was presented, immediately appeared a paragraph entitled: Adversarii, where the defenseless opponent was simply supposed to be defeated. In the same style, the part of often astonishing objections was edited, as well as even more astonishing clear and concise responses to these objections. Today's situation also conditions our view of the way of teaching itself proceeds which is deprived of its paternalistic character, gaining, or rather regaining, its proper serving function.

Today's man is unable to give a confession of faith like "in blindness," confess truths of faith closed in systems, methods and treatises. True community is the goal of his aspirations and endeavors. Forms, institutions, organizations and structures are then accepted as long as they fulfill a subordinate role in relation to this community. A typical symptom of altered spiritual attitudes is - however we would look at this issue - an attempt to revalorize corporeality and emotional life. One and the other sphere of his existence is to be lived by a man as a symbolic reality, simply as a mystery. The thought of a modern man is oriented towards the future. He knows that every new discovery opens up a sequence of new questions and new perspectives. Man is aware that he himself has also been involved in a powerful stream of evolution, this latter idea finds its expression in an unprecedented way in the Christian writings of Teilhard de Chardin.

We continue to discern in the man of our time the indomitable urge to this kind of reconstruction of the world, so that it becomes habitable and able to develop further. The voices of cultural historians (A.J. Toynbee) can be heard, according to which the first symptoms of the common culture of the world can already be seen.

Another thought - also not without significance for contemporary studies on the problem of the Eucharist - is the observation that the culture in which we live is the culture of large cities and human communities, whose phenomenon reveals new problems of human co-existence. In architecture, it manifests itself in striving to achieve the effect of plasticity of space. Bold church buildings are designed to meet the requirements of a number of functions. In painting, art and sculpture, we notice a fascination with original archaism. Black art, Aztec art, Byzantine iconography, Romanesque frescoes are being rediscovered. In a word, we become witnesses of a feverish search for elementary and symbolic means of expression. 
Today's artist seems to hold the conviction that absolute reality surpasses and excesses above everything created by man. At the same time, we observe the tendency to reproduce the extremes of what is ugly and imperfect. It can therefore be said that contemporary, avant-garde aesthetics, leaning towards the absolute, and thus creates a religious climate, and fertilizes the soil for the germination of religious values. Similar considerations could be made about poetry. To what extent and how far is the word the transparency of the Absolute. Word Incorporated. The causative Word, the Word of agency entrusted to the priest $^{6}$. However, this all would exceed the framework of our intentions. The above remarks should, at least in part, be more clearly related to the Eucharist. If we consider the twentieth century as a period of contemporary tendencies in the Eucharist, then we can divide it - most reasonably - into two parts: the first part is completed by the first half of the $20^{\text {th }}$ century, and the second half by the second half of the same century.

\section{The First Half of the Twentieth Century - a Turn towards Tradition}

At the beginning of the twentieth century, the first signs of renewed reflection on the Eucharist could be noticed. Looking for ways leading to Tradition, L. Billot (1931) and M. de la Taille (1933) speak of the Eucharist as sacrificium in signo vel in sacramento. In the Eucharist they see the symbol, the sacramental sign of the onetime reality of the Cross. At the same time, they regarded this sign as being strictly related to the Sacrifice of the Cross. These theologians thus entered an intermediate path, running between the two extreme positions of the post-Trent theology. On the one hand, they avoided the hard reality of accepting a new sacrifice, analogous to the sacrifice of the Cross, and on the other hand they distanced themselves from the view leading to the claim that the Eucharist was only a pure sign, and consequently having no connection with the reality of the Sacrifice.

The theory of citizenship in theology was elaborated by A. Vonier (1938) and above all by O. Casel (1948). Reflecting on liturgical texts and on Thomistic science, as well as conducting studies on the history of religion, Casel elaborated new intuitions with regard to the problem of the Eucharist. Referring to the 
ancient concept of mysterion, he developed his theology of mystery presence (Mysterien-Gegenwart). In symbolic activities and through these activities and through the word of the liturgy, Christ's saving actions become present. The commemoration that takes place in the cult can be simply identified with the presence of one of God's works?

Within the cult activities the Christian becomes not only a participant in the fruits of Christ, the acts of salvation but these acts become present themselves, namely through Word and rituals. The real presence of Christ and his salvific work are thus realized under the concealment of symbols.

Not all elements of Casel's theory are acceptable. Its main ideas have, however, become a permanent property of modern doctrine about the Eucharist. Thanks to this Benedictine theologian, we have gained an insight into the full richness of the Eucharistic Feast. Casel created the basis for a synthesis that has been missing since the time of Council of Trent, in which sacrifice, communion and real presence harmoniously connect with each other. Let us not fail to mention here that Casel's theory had unexpected ecumenical implications. Advocates of evangelism have made it clear that this turn in Catholic theology about the Eucharist can be the basis for agreement on one of the most controversial issues. In the long-term Catholic-evangelical disputes concerning the Sacrifice of the Cross and the sacrificial rituals of the Mass, it turns out that the statements about one and the other aspect of the sacrifice lie very close to each other, and so close that it is difficult to believe that fierce polemics is even possible after period of four hundred years ${ }^{8}$.

\section{The First Half of the Twentieth Century. Today's Eucharistic Thought}

Reflecting on the Eucharist, theologians did not limit themselves to referring to traditional thought. The last fifteen years have especially brought new solutions. It is characteristic that the attention of theologians was again focused on the subject of real presence. This presence, however, is not considered by theologians as an isolated event but as a peak of the presence of the entire salvific event of Jesus taking place in the assembly of the ecclesial community.

7 Cf. O. Casel, Das christliche Kultusmysterium, Regensburg 1960, 79.

8 "[...] das ist sicher, dass beide Aussagen sehr nahe beieinander liegen, so nahe, wie es nach vierhundert Jahren einer kampfdurchtobten Geschichte nicht fur möglich gehalten werden sollte". H. Asmussen, Abendmahl und Messe, Stuttgart 1949, 24. 
Attempts at new reflections develop on the basis of the existential phenomenology mentioned above. The right and even the obligation to carry out new reflections deepening the study of the Eucharist is implied in the opinion of many modern theologians by certain statements of the Council of Trent considered by them as imperative.

Here are two Council statements: Quae conversio convenienter et proprie a sancta catholica Ecclesia trans substantia te est appellata (D877), and: ... quam quidem conversionem catholica Ecclesia aptissim e transsubstantiationem appellat (D 884). One can conclude that they do not exclude the possibility that someday theology will elaborate a concept more appealing to the mentality of believers.

With all the immutability of the content of Revelation, the very notions of this expressive content are associated with a specific epoch and intellectual culture of this epoch. If, then, we conclude further, the Fathers of Trent used, as children of their times, the Aristotelian scheme of concepts, we today - as children of the $20^{\text {th }}$ century - have the right and duty to investigate this problem using contemporary conceptual apparatus. What is characteristic of people of the modern day is the fact that we all do not feel like Aristotelians anymore. We do not think and are even no longer able to think in terms of substance and accidents. We are more sensitive to the world of personal relationships today. The personalistic concept of man found itself at the center of the phenomenological way of thinking.

Modern man - we can regret it more or less - is less concerned about metaphysical issues. Yes, man wants to explore the ultimate meaning of things but he does not investigate mythological principles. He is guided by another question: what is the meaning of these things? Their purposefulness? Their meaning assigned to them by man? We are more interested in the meaning of things granted them by man than in what they are in themselves. In our philosophical investigations, we constantly make substitution processes, whether consciously or not: we consider things in their relation to a man or a person, and only in this respect they are interesting to us. Actual presence is not just something objective, a reality lying "outside of me," independent of me, having no relation to me; real presence is a manifestation of the existence that concerns me personally. Here one should appreciate the prominent contribution of several contemporary theologians who were able to exploit the phenomenological way of perceiving things in this manner. Maintaining continuity with the doctrinal line of Council of Trent, these theologians have exposed the thesis of this council Institutum ut sumatur (D 878). 


\section{Developing of Contemporary Intuitions}

In terms of thinking about existential phenomenology, the Eucharist is presented with a certain predilection as a feast of the Christian community. The Coena Domini of Saint Paul is interpreted as a community of the table with the Risen Christ, where the Risen Christ himself is the Host of the feast, while the commune is its guest. The presence of the Lord under the species of bread and wine is therefore seen in a personalistic manner; the species of bread and wine seen in this perspective are gifts of the Host of the Feast.

Just like in everyday life, bread and wine, as gifts of the Host of the feast, are more than mere biological food - they are an expression of the owner's love and friendship - so the species of bread and wine are essentially a means through which Christ manifests and realizes his grace and love for the commune. Bread and wine are identical with the Lord, as long as He alone is identifying himself with His gift. These gifts are his transparency, manifestation.

In the consciousness of today's man, the idea has become elaborated, that the body is the transparency and manifestation of the spirit. The material sign is the carrier of spiritual and internal content. In our opinion, our body is realization of our personality ${ }^{9}$. This category can be successfully applied to the act of understanding, in faith, to the Eucharist: the Person of Jesus Christ manifests Himself in the bread, that is, in the body that experiences a kind of extension to our times through the bread which Christ himself chose as a symbol of his Body.

Let us make a further step forward. In the Eucharist, it is about presence considered in the human manner, i.e. we do not refer to mere physical presence (some praesentiam circumscriptivam), the physical location of things. I can speak of human presence only when there is actually personal contact between myself and another person, when I can see the other person, shake his/her hand, exchange gifts under any form. It seems that this reflection can be applied to the Eucharist. Emphasizing the fact that Christ wants to be present among us, we overcome the too static and too-substantive notion of the Eucharist. Jesus wants to be present through His Body and through bread, which is an extension of this body. What we mean here is consistent with the doctrine of the Council of Trent, which develops a scholastic concept of concomitance. Namely, the reality that is present vi verborum is the Body first; but - along with the Body, the human

$9 \quad$ The German language knows several terms Körper and Leib. Körper is a body with a specific shape, weight, etc., while Leib is the subject of personal communication, an expression of love, hatred and friendship. 
soul of Jesus - the Word of God is also made present. Therefore, not only the Body is present, but also the Word, which became a human being.

That is: It is even possible to go beyond and the supra-Council term Institutum ut sumatur, by more precisely defining the concept of sumatur. Christ does not so much want to gather us around his table to feed us with His food; through receiving the Eucharist the friendship between God and man is renewed, at the Eucharistic Table we are included into the whole of the saving event of Christ. This kind of communion is Sacrifice.

\section{Critical Moment}

Here we are touching the critical moment of our deliberations. A disturbing question irresistibly appears: does not this type of Eucharistic vision lead to dilution or even negation of the mystery in its ontological sense? Is reality regarded only as a feature which I personally attribute to a thing? Considering this problem more fundamentally, from the point of view of another field of theology one can ask: is God only the result of our interpretation of the world, a sign of our existence, or is it a superior being that existed prior to us, constituting a priori my existence? My vis à vis? To illuminate this problem, one must go beyond phenomenological data, beyond the signs of their meaning, beyond manifestation and transparency, to the very presence of Jesus Christ, to the presence of Christ in his humanity. Medieval ontology presented here the proposition of a substance, that is a concept which corresponds to the deepest essence of being. We can and we have the right to talk about trans-signification and trans-finalization, however, under the condition that we will be understood correctly: Christ gives bread a truly new meaning through His creative word; if so, there is no point in claiming that His presence is the result of my faith or the faith of the Church.

We are dealing here with God's creative and effective presence which is the creative power that detects and activates my faith. To avoid any misunderstandings, we must compare faith with reason because things are the same here. Human reason grants things their meaning and thus transforms them but reason also discovers the sense of immanent things at the same time. The world was rational before man even thought about it. Faith attributes a new meaning to gestures and things but at the same time it discovers the realities that God has renewed through the Logos, faith also deciphers the meaning of the thing that God reveals to us under the cover of signs. In this way, faith participates in the Holy Spirit who lives in us, in God's view of things. If we define the Eucharist 
as Mysterium fidei, then faith must be regarded as a way of objectively seeing things, as an ability to detect the effective presence of the risen Lord hidden under the cover of the bread and chalice. The risk of distortion proves its deep connection with the structure of our perception of things.

We are willing to re-emphasize one of the elements to its extreme form. It seems that new tendencies in Eucharistic theology result in two achievements: they enrich the study of the Eucharist with a personalistic factor, a moment that belongs to the treasury of our faith as well as the truth about transubstantiation, and at the same time they give justification or at least they require, a new justification and revaluation of the ontological foundation of the Eucharistic presence. However, new interpretations complement the traditional formula of faith, and they are not able to replace it. It is not enough to pay attention to the Eucharistic activity in which we are involved; attention should also be focused on the Person itself, who is acting and manifesting oneself. Indeed, Christ is present there to be consumed in the form of the Eucharist, but He is present there.

\section{Towards an Appropriate Solution to the Problem}

The assessment of contemporary attempts to interpret the phenomenon of real presence cannot be made today without taking into consideration the encyclical Mysterium fidei by Paul VII. It seems that the above way of presenting new trends in the doctrine of the Eucharist coincides with the content of teaching of the encyclical, which states as follows: "After the transubstantiation of bread and wine, they acquire a new meaning and a new function without any doubt because they are no longer common bread and common drink, but a symbol of a sacred reality and a sign of spiritual food; but they take on new meaning (novam significationem) and a new final (novum finem) because they contain a new reality which we rightly call an ontological. However, there is no longer hidden what was before, under the aforementioned species, but something completely different, and it is not only because of the particular conviction of the Church but in fact because after the transformation of the substance that is the essence of bread and wine into the Body and Blood of Christ, there is nothing left of bread and wine except the very figures under which Christ resides in His entirety and not diminished in his physical 'reality', present even in a bodily manner, although not in the same way in which bodies are located in space."10 
These words of the encyclical, undoubtedly the most important in the entirety of its lecture, are nothing more than a description of the Trent Council's formula of transubstantiation. At the same time, however, and this is important to us, they contain certain indications encouraging to go beyond the formula of Trent Council:

a. The sensualist-physical notion of presence, still widely popular among people is being rejected ${ }^{11}$;

b. The encyclical adopts an open attitude towards scholastic teaching, defining the concept of "substance" with the help of the term "reality," and thus the document of the Pope is no longer connected with the old philosophical-natural term of substance;

c. When the encyclical in the words which follow immediately this statement defines transubstantiation by the term transelementation ("transelementation"), it distances itself cautiously again from the classical interpretation; the concept of transelementation is much wider and indefinite than transubstantiation.

The above considerations imply that the understanding of contemporary aspirations in the study of the Eucharist presupposes the knowledge of the thought of Trent and the encyclical Mysterium fidei. The new currents of Eucharistic theology are consistent with the teaching of the past.

E. Schillebeeckx holds the opinion that the concepts of trans-finalization and trans-signification are only terms that expand the mystery of change with new aspects but do not express it ${ }^{12}$. Schillebeeckx is not content with a mere phenomenological interpretation deprived of the metaphysical condensation of presence; the mystery of transformation is achieved through the power of the creative action of the Holy Spirit, the transformation is, according to the theologian of Nijmegen, "an act of new creation."

11 Cf. Roman synod of 1059 against Berengarius, who had to sign the following Confession offaith: “...panem et vinum... post consecrationem non solum sacramentum, sed etiam verum corpus et sanguinem Domini nostri Iesu Christi esse, et sensualiter non solum S acramento, sed in veritate manibus sacerdotum tractari et frangi et fidelium dentibus atteri." D 690. In the teaching of the Catechism, it was commonly taught that the Host accepted was not allowed to be bitten which caused insurmountable scruples on the part of the faithful.

12 E. Schillebeeckx, In der Eucharistie hängen Transsubstantiation ('conversio entis'; was ist die vorhandene Wirklichkeit? Christi Leib) und Transsignifikation (neue Sinn-Stiftung oder Zeichen-Wert) unlöslich zusammen, aber man kann sie nicht schlechthin identifizieren. Die eucharistische Gegenwart, Düsseldorf 1967, ch. 101. 


\section{Practical and Pastoral Remarks}

In conclusion, we present a few practical remarks about the possibility of exploiting theological professional terms in preaching ${ }^{13}$.

a. Because professional theological language is not the language of the kerygma, it should not normally be used during sermons. However, it can be successfully used for meetings in smaller groups (e.g. adult catechesis, student seminars, etc.), and it is all the more advantageous that the concepts of trans-finalization and trans-signification provide a fertile ground for carrying out explanatory explanations.

b. Close attention should be paid to the fact that these concepts do not express anything completely new but attempt to express various aspects of New Testament data in a different conceptual framework. They are not really anything but an exemplification of the words: "This is my Body." Listeners will surely become enriched by the experience that the same New Testament doctrine can be expressed in different ways.

c. It is also necessary to show the difference between the revealed truth and its wording. It is also necessary to emphasize the difficulties that the concept of substance implies with regard to contemporary mentality whose difficulties only concern the theological interpretation in no way affecting the truth of faith itself. One should not deny that theology has its limits; it sometimes takes centuries of intellectual effort to get an approximate insight into some truth of faith, which is evidenced by the history of dogmas. Indicating the limits of theology will certainly not be harmful with regard to the preaching itself. Finally, the fact that we do not even know and we will not know how is the transubstantiation process actually carried out, should not bother us, provided that we would be capable of saving our eucharistic - fully rational - piety.

13 Further remarks follow the thoughts included in the study: H. Volk, Fr. Wetter, Geheimnis des Glaubens, Mainz 1968, 27ff. 